\title{
JUURNAL.RU
}

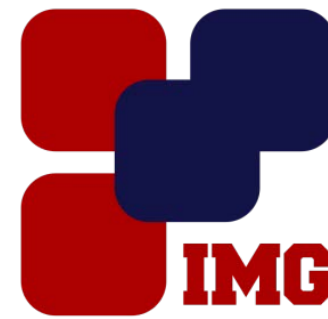
IYANOY Management GROUP

Гордеев А. А. Московский государственный университет им. М. В. Ломоносова Москва, Россия

doi: 10.18411/lj-28-02-2017-2-11

idsp 000001:lj-28-02-2017-2-11

\section{Управление персоналом в условиях инновационной экономики}

\section{Аннотация}

В работе анализируются требования к современному подходу управления персоналом в условиях инновационной экономики.

Ключевые слова: управление персоналом, инновационная экономика, интеллектуальные сотрудники, humanbeingmanagement.

\section{Abstract}

The paper analyzes the requirements of modern human resource management approach to an innovative economy.

Keywords: human resource management, innovative economy, knowledge workers, human being management.

Информационная революция, четвёртая технологическая революция - по сути, промышленная революция, окончательно перевели экономику в постиндустриальную фазу.

Безусловно, этот процесс проходит неравномерно, ещё много производств, отраслей, целых стран находятся на предыдущей ступени развития.Но основные достижения, основная прибыль будет производиться, и аккумулироваться именно в постиндустриальных секторах и отраслях.

Ричард Флорида в конце прошлого века ввёл понятие «креативный класс» как основную производительную силу новой эпохи. Он относил к этому классу людей «творческих» профессий, «продающих» или «зарабатывающих» своим талантом. Он говорил, что люди творческих профессий живут в своей системе координат, своей системе ценностей, в новой корпоративной культуре [1].

Переход к постиндустриальной экономике - ее ещё называют «экономикой знаний»- приводит к тому, что все больше «традиционных» отраслей переходит в новый «креативный» формат, начинают жить в новой корпоративной культуре

Офисы«Яндекс» и Google, производства Илона Маска, ведущие инжиниринговые центры, наукоемкие производства - это уже креативные отрасли, это уже творческие коллектив.И это уже не традиционная «кадровая политика», а система «развития талантов». 
Если мы хотим быть лидером на рынках постиндустриальной экономики, то мы должны чётко осознать, что главная, если не единственная, для нас ценностьэто человек, наш сотрудник, член коллектива. А это требует принципиальных изменений во всей системе кадрового менеджмента.

Почему старые методы больше не работают эффективно? Появился новый тип - интеллектуальные сотрудники [2].

1. Происходит изменение системы ценностей самих сотрудников, их уже не удовлетворяет факт получения заработной платы, их волнует самореализация и социальное положение в трудовом коллективе.

2. У бизнеса появилась новая миссия - это служение людям, развитие навыков и талантов, повышение уровня жизни общества, искоренение бедности.

3. Изменение целей бизнеса,выгоднее не производить больше и дешевле, а создавать что-то новое и иное.

Все большее значение играет культура организации, корпоративная культура - понятие, которое появилось в конце прошлого века.

Цель руководителя - развить эффективную культуру организации, чтобы работник шел на работу, как в свою собственную фирму, чтобы у него было желание и стремление работать.

Новые работники теперь не дадут приказывать, для современного сотрудника неприемлема мысль, что нужно безоговорочно выполнять любое пожелание начальства. Слово «подчиненный» произошедшее от словосочетания «место под чином»- следует убрать из оборота, ведь теперь у сотрудника место- у объекта цели.

Важный аспект работы менеджера в инновационной экономике вовлечение сотрудников в обсуждение, решение проблем.Раньше начальник говорил, что делать и как, заранее обдумав. Сотрудник, поняв, что их обсуждения носят формальный характер и ненужные идеи, относится к этому формально.Теперь: не только обсуждение совместное, но и решение.

Главная проблема - управление человеком не как функцией, а как личностью. Появился новый термин «humanbeingmanagement», означающий управление человеком, а не подчиненным.

Но перед тем как научиться управлять таким сотрудником, его надо найти. И тут мы сталкиваемся с еще одной проблемой - поиск интеллектуального сотрудника.

Изучив требования, какие предъявляет такой интеллектуальный сотрудник работодателю, можно заметить, что для него возможность самореализации, интересные задачи и наличие команды единомышленников не менее важно, чем зарплата и социальный пакет. Специалисты, которых единицы, иногда соглашаются работать за меньшую зарплату, если ощущают себя комфортно в данном коллективеи обстановке.

Одна из главных задач работодателя не просто найти специалиста, но и сделать его компетентным при постоянно обновляющихся технологиях, повышая его квалификацию и развивая согласно последним требованиям. Это касается как высокотехнологичных специальностей, так и представителей сферы обслуживания, например, парикмахеров или косметологов. Главное, что эти сотрудники сами замотивированы на обучение и готовы к самосовершенствованию при любой возможности[3]. 
Приняв, что обучение таких специалистов - это обязательный фактор его развития и удержания, стоит также отметить, что через 5-10 лет этому сотруднику будет необходим новый опыт, в силу того, что ему может наскучить играть ту же роль, поэтому необходимо предложить ему роль наставника. Ведь в тех компаниях, где он чувствует себя частью команды, он готов заниматься наставничеством бесплатно или за символические деньги. Потому что это часть его миссии и потому что он понимает, что это общие цели, как его, так и компании.

Работодатель должен быть готов ко многим трудностям [4]:

1. Право на ошибку.

2. Нестандартные требования.

3. Нестандартное поведение.

4. Затраты на обучение.

5. Повышенные требования к коммуникативной компетентности руководителя.

Право на ошибку. Так как в наши дни бизнес переориентируется на изобретение нового и иного, а не изготовление крупных масштабов да дешевле, менеджер должен быть готов к тому, что специалист будет совершать ошибки на пути создания этого иного продукта. Им нужна свобода поиска нового, а значит и свобода на ошибку.

Затраты на обучение. Исследование всемирного банка показали, что $16 \%$ экономического роста в странах с переходной экономикой обусловлены физическим капиталом, $20 \%$ - природным и целых $64 \%$ - это инвестиции в человеческий капитал, в его развитие и обучение.

Повышенные требования к коммуникативной компетентности руководителя. В современных условиях будет эффективен тот менеджер, который готов организовать свою команду как лидер. Ведь как сказано выше - главная проблема менеджмента - это подход к сотрудникам как к функциям, а не как к личностям. Герхард Кюнхайм, СЕОВМW, говорил:«80\% проблем фирмы обусловлены «человеческим фактором» в самом широком его значении:Самочувствием человека в семье и обществе, его интеллектуальном и профессиональном развитии» [5].

Руководителю теперь придется способствовать благополучию своего сотрудника не только на рабочем месте, но и в жизни в целом, если он хочет, чтобы специалист мог выкладываться на работе, не задумываясь об остальных проблемах - это и есть задача и цельһumanbeingmanagement. 


\section{Литература}

1. Флорида Р. Креативный класс: люди, которые меняют будущее // М., Издательский дом «Классика-XXI», 2007.

2. MaslovV. I.Newdemandsforeducationintheeraofthe

4thindustrialrevolution/ Экономикаиуправление: проблемы, решения, 2016, №6.

3. Романова И. Н. Инновационные процессы в управлении человеческими ресурсами // Экономика и управление народным хозяйством. Сб. статей VII Международной научно-практической конференции. - Пенза: Приволжский Дом знаний, 2016. - 124 с.

4. Кузьминых Н.А. Система управления инновационным развитием промышленного производства // Экономика, статистика и информатика. Вестник УМО. - М.: МЭСИ, 2010. - № 1. - С. 49-57.

5. Очковская М. С. Инновации в человеческий капитал как необходимое условие качественного экономического роста // Материалы Международной конференции «Ломоносов - 2005», Москва, 2005, с. 104-105. 